\title{
INVENTARISASI CERITA RAKYAT DARI KABUPATEN DEMAK MELALUI APLIKASI BUKU DIGITAL (E-BOOK) INTERAKTIF
}

\author{
Noor Hasyim ${ }^{1}$, Ali Muqoddas ${ }^{2}$ \\ ${ }^{1,2}$ Program Studi Desain Komunikasi Visual \\ Fakultas IImu Komputer, Universitas Dian Nuswantoro Semarang \\ hasyim.nahl@gmail.com ${ }^{1}$, ali.dinus.@gmail.com ${ }^{2}$
}

\begin{abstract}
Abstrak
Cerita rakyat merupakan salah satu keunikan budaya yang dimiliki oleh setiap daerah, termasuk daerah Kabupaten Demak. Cerita rakyat mampu menjadi sarana pendidikan nilainilai luhur yang diwariskan oleh pendahulu kepada generasi mendatang. Inventarisasi cerita rakyat ini penting dilakukan seiring modernisasi yang terjadi di segala bidang menjadikan masyarakat setempat khususnya generasi muda banyak yang tidak mengetahui cerita tersebut. Di zaman modern inventarisasi harus juga dilakukan denga cara modern pula. Salah satu caara untuk mengemas cerita rakyat di zaman modern adalah menggunakan aplikasi buku digital yang dibuat interaktif. Perkembangan komputer tablet berbasis touchscreen semakin menambah interaktif gambar bergerak yang disajikan di dalam aplikasi buku digital.
\end{abstract}

Kata Kunci: Buku digital, Cerita Rakyat, Folklor Demak

\section{PENDAHULUAN}

Masyarakat Indonesia memiliki kebudayaan yang sangat beragam. Kebudayaan tersebut memiliki keunikan-keunikan tersendiri sesuai daerah kebudayaan tersebut berasal. Salah satu keunikan budaya yang dimiliki oleh Indonesia adalah Folklor. Folklor sendiri bisa diartikan sebagai kebudayaan yang disebarkan secara turun-temurun. Salah satu jenis folklor adalah carita rakyat. Cerita rakyat mampu menjadi sarana pendidikan nilai-nilai luhur yang diwariskan oleh pendahulu kepada generasi mendatang.

Salah satu daerah yang memiliki banyak cerita rakyat adalah Kota Demak. Kota Demak merupakan kota bersejarah yang terkenal sebagai Kota Wali. Cerita rakyat yang berada di Kota Demak merupakan aset budaya dan dapat dijadikan sebagai sarana pengembangan pariwisata di daerah tersebut. Penginventarisasain cerita rakyat tersebut dianggap penting untuk mempermudah pelestariannya. Penginventarisasain cerita rakyat Demak juga bertujuan meningkatkan apresiasi kultural masyarakat setempat dan dapat dijadikan sebagai salah satu wujut pengembangan budaya nasional. Inventarisasi cerita rakyat ini penting dilakukan seiring modernisasi yang terjadi di segala bidang menjadikan masyarakat setempat khususnya generasi muda banyak yang tidak mengetahui cerita tersebut. Perkembangan teknologi memberikan banyak pilihan menarik untuk diperhatikan dan menyisihkan cerita rakyat yang terkesan tradisional. 
Inventarisasi cerita rakyat Demak pernah dilakukan oleh Alaydrus Dkk pada tahun 1994. Hasil inventarisasi cerita rakyat tersebut masih berupa media konvensional dan tidak melibatkan teknologi. Perkembangan teknologi informasi memberikan pengalaman hidup baru yang belum pernah dijumpai sebelumnya. Piliang (2005:221) menuturkan bahwa segala macam realitas masa lalu, sekarang telah digantikan oleh realitas baru. Dunia berkembang menuju zaman dimana kertas sudah tidak digunakan lagi, yang disebut era "the death of paper culture". Perkembangan teknologi menjadikan seluruh pekerjaan dilakukan secara digital. Surat sekarang tidak membutuhkan kantor pos karena digantikan dengan email, kartu ucapan selamat digantikan dengan SMS, tenis dilakukan dengan virtual, begitu pula buku yang dicetak menggunakan kertas sekarang digantikan dengan buku digital.

Perkembangan teknologi informasi yang cukup populer saat ini adalah multimedia, yang mampu mampu mengubah satu media ke media lain secara leluasa, yakni dari media teks ke media gambar dan suara, maupun media interaktif yang melibatkan berbagai indera. Salah satu perkembangan multimedia adalah buku digital yang dibuat interaktif. Berbagai konsep e-book atau buku digital sekarang hadir di masyarakat dengan berbagai alternatif media. Mulai dari e-book berbasis cakram (CD), padat, website, hingga aplikasi (app). Perkembangan komputer tablet berbasis touchscreen semakin menambah interaktif gambar bergerak yang disajikan di dalam buku digital. Buku digital dibuat secara interaktif tidak hanya menyajikan teks yang dihiasi gambar statis namun juga dihiasi dengan berbagai tampilan gambar bergerak yang dapat dimanipulasi. Aplikasi buku digital merupakan media yang cocok untuk inventarisasi cerita rakyat Demak di zaman modernisasi ini.

\section{METODE PENELITIAN}

Peneltian ini menggunakan metode desain dan eksperimental, yaitu dengan melakukan eksperimen pengembangan desain aplikasi buku digital interaktif. Sebelum melakukan perancangan dilakukan metode kualitatif. Metode kualitatif dilakukan untuk menghasilkan data deskriptif berupa kata-kata atau lisan dari orang dan perilaku yang diamati. Dalam penelitian ini, penulis akan menjadi pencerna, pelaksana, pengumpul data, penganalisis, dan pelapor hasil penelitian. Dengan metode kualitatif akan didapatkan gambaran secara detail tentang objek penelitian yaitu cerita rakyat yang terdapat di kabupaten Demak.

Setelah dilakukan metode kualitatif maka dilakukan metode eksperimentatif yang terdiri dari beberapa tahapan sebagai berikut:

a. Konsep (concept)

Merupakan proses kreatif penciptaan ide, visual mapping, konten aplikasi, tujuan dan konsep komunikasi.

b. Desain (design)

Merupakan tahapan menentukan gaya desain yang akan digunakan dalam perancangan aplikasi buku digital. 
c. Pengumpulan Bahan (material collecting)

Merupakan tahap pengumpulan bahan/ material aplikasi buku digital berupa clipart, image, animasi, audio, berikut pembuatan grafik, foto, audio, dan lain-lain yang diperlukan untuk proses perancangan.

d. Pembuatan (assembly)

Merupakan tahap seluruh objek aplikasi buku digital dibuat. Pembuatan aplikasi berdasarkan storyboard, flowchart view, struktur navigasi, atau diagram objek yang berasal dari tahap desain.

\section{PEMBAHASAN}

\subsection{Folklor dan Cerita Rakyat}

Folklor dapat dimaknai sebagai kekayaan tradisi, sastra, seni, hukum, perilaku dan apa saja yang dihasilkan secara kolektif yang tersebar dan diwariskan secara turun temurun (Danandjaja, 1997). Danandjaja juga menjelaskan bahwa foklor adalah bagian kebudayaan yang bersifat tradisional, tidak resmi (unofficial), dan nasional. Folklor mencakup semua pengetahuan, nilai, tingkah laku, asumsi, perasaan, dan kepercayaan yang tersebar dalam bentuk-bentuk tradisional melalui kebiasaan. Folklor merupakan milik bersama dari kolektif tertentu dan umumnya bersifat polos sehingga sering terkesan spontan.

Pengidentifikasian folklor dapat dikenali dengan beberapa ciri yang nampak padanya. Brunvand dalam Danandjaja (1997:29) menyebutkan bahwa jenis Folklor memiliki cakupan yang sangat banyak. Pengelompokan folklor secara garis besar dapat dikelompokkan menjadi 3 bagian, yaitu: foklor lisan (verbal folklore), folklor sebagain lisan (partly verbal folklore), dan folklor bukan lisan (non verbal folklore). Tiga wujud folklor ini dapat menampakkan dirinya ke dalam tiga wujud nyata. (1) Bentuk oral dan verbal (mentifacts). Berupa ujaran rakyat, julukan, dialek, ungkapan dan kalimat tradisional, pertanyaan rakyat, mitos, legenda, nyanyian rakyat, dan sebagainya. (2) Berupa kebiasaan dan sosiofacts (kinesiologik), yang mecakup folklor lisan dan bukan lisan, seperti kepercayaan rakyat, adat-istiadat, pesta, dan permainan rakyat. (3) Berupa material (artefak) seperti seni kriya, arsitektur, busana, makanan, dan lain sebagainya, yang hanya menyangkut bentuk fisik semata.

Cerita rakyat adalah cerita yang pada dasarnya disampaikan secara lisan (Semi, 1988:79). Berdasarkan pengertian tersebut, cerita rakyat termasuk folklor lisan. Semi (dalam Oktalina, 2013:4) menyebutkan bahwa cerita rakyat mempunyai lima fungsi sosial yaitu :

1. Menghibur, melahirkan rangkaian cerita yang indah dan enak untuk dinikmati.

2. Mendidik, memberikan pelajaran kearifan untuk menjalani kehidupan.

3. Mewariskan, menjadi alat penyampaian nilai-nilai secara turun-temurun.

4. Jati diri, menjadi ciri khas tersen diri bagi masyarakat.

5. Tradisi, meneruskan tradisi suatu bangsa kepada masyarakat yang akan datang. 


\subsection{Cerita Rakyat Kabupaten Demak}

Demak merupakan kota sejarah yang dikenal oleh masyarakat sebagai Kota Wali (Wardah, 2013:67). Demak yang dikenal sebagai kota wali memiliki sejarah panjang sebagai tempat berkumpul para wali penyebar ajaran Islam di Jawa. Di Demak pernah berdiri kerajaan Islam pertama di Jawa yang dipimpin oleh raja pertamanya yaitu Raden Patah. Karena memiliki keunikan sebagai tempat berkumpulnya para wali, Demak memiliki banyak cerita rakyat yang sejak dahulu disampaikan secara turuntemurun melalui bahasa lisan.

Alaydrus Dkk pada tahun 1994 telah menginvestasikan beberapa cerita rakyat yang ada di Daerah Demak. Cerita rakyat Demak tersebut diperoleh dari studi kearsipan hingga wawancara langsung kepada masyarakat setempat. Cerita rakyat yang berhasil diinventarisasikan diantaranya sebagai berikut :

1. Bah Sapeti, bercerita tentang asal usul Dukuh Gribigan, Desa Wedung, Kabupaten Demak, serta perjalanan hidup Sapeti yang mengawinkan anaknya dengan harimua titisan Raja Kediri

2. Telaga Sentanu, bercerita tentang Raden Burham, keturunan dari Raden Benawa, putra Sultan Pajang yang berusaha mencari obat untuk menyembuhkan Dewi Omba Reka di Telaga Sentanu. Telaga Sentanu yang terletak di samping Desa Berahan konon saat itu merupakan tempat pemandian para bidadari.

3. Ki Ageng Nambangan, bercerita tentang kisah Ki Ageng Tompe, seorang guru agama yang memiliki berbagai karomah. Dengan berbagai karomah tersebut $\mathrm{Ki}$ Ageng Tompe menjadi terkenal di daerahnya yaitu desa Tambirejo, kecamatan Dempet, Kabupaten Demak. Kepupuleran Ki Ageng Tompe membuat iri Raden Prawoto yang akhirnya mengadu kepada Sultan Trenggono dengan berbagai Fitnah sehingga Ki Ageng Tompe dihukum Sultan Trenggono menjadi seorang juru tambang. Juru tambang adalah orang yang bertugas menyeberangkan penduduk dari desa ke kota lewat rawa dengan perahu.

4. Asal Mula Watu Kenong, bercerita tentang Ki Bagus yang menyabda gamelan menjadi sebuah batu karena percekcokan yang tejadi antara penduduk daerah Dukuh dan penduduk daerah Kadilangu.

5. Telaga Bengkah, bercerita tentang kisah jokaryo, salah seorang murit Sunan Kalijaga yang diperintahkan membuat telaga oleh Pringapus di desa Wonosekar, Kecamatan Karangawen Kabupaten Demak.

\subsection{Buku Digital (E-book)}

Dalam Oxford dictionaries buku digital atau e-book merupakan versi elektronik dari buku cetak yang dapat dibaca pada komputer atau perangkat genggam yang dirancang khusus untuk memfasilitasi buku ini. Senada dengan definisi ini suwarno (2010: 74) mengatakan bahwa e-book adalah versi elektronik dari buku. Jika buku pada umumnya terdiri dari kumpulan kertas yang berisi teks atau gambar, e-book berisi informasi digital yang juga dapat berwujud teks atau gambar. Menurut Dansei (2008:107) e-book adalah buku yang memiliki tampilan sebagaimana buku tradisional namun disimpan pada konten digital. Bisanya buku digital dapat diupdate secara langsung dari bookstore atau website yang menyediakan pelayanan penjualan buku digital. 
Vasileiou dan Rowley (dalam Ardiansyah,2012 : 84) menyebutkan bahwa buku digital adalah sebuah obyek digital berupa teks atau konten lainnya, yang dihasilkan dari pengintegrasian konsep buku dengan fitur-fitur yang dapat digunakan pada lingkungan elektronik. Buku digital biasanya memiliki fitur-fitur untuk memudahkan penggunaan seperti fitur pencarian, fungsi referensi silang, hipertext link, obyek multimedia, serta fitur-fitur interaktif. Bhairawa (2011) mengatakan bahwa buku digital adalah salah satu teknologi yang memanfaatkan komputer untuk menayangkan informasi multimedia dalam bentuk yang ringkas dan dinamis. Buku digital dapat mengintegrasikan tayangan suara, grafik, gambar, animasi, maupun movie sehingga informasi yang disajikan lebih kaya dibandingkan dengan buku konvensional.

Negroponte (1998:23) memaparkan keunggulan dari digitalisasi atom menjadi bit diantaranya adalah kemampuan digital untuk memampatkan data yang dapat menghemat biaya. Ketika semua media menjadi digital, akan muncul bit baru yang dapat menerangkan bit baru. Bit-bit akan dengan mudah bercampur secara bebas. Contoh kongkritnya adalah gabungan video suara dan teks yang dinamakan multimedia. Bit adalah istilah yang dibuat oleh Negroponte yang merujuk pada digital, sedangkan atom adalah istilah yang merujuk pada analog. Dengan adanya internet, mengiriman buku digital yang berbentuk bit ini juga jadi lebih mudah. Selain itu, hadirnya isu "Desain Ramah Lingkungan" menjadikan buku digital menjadi salah satu solusi untuk mengurahi penggunaan kertas sehingga penebangan pohon dapat dikurangi.

Dari beberapa uraian di atas dapat disimpulkan bahwa kelebihan buku digital dibandingkan buku cetak adalah sebagai berikut :
a. Mudah dibawa
b. Tidak lapuk
c. Mudah digunakan
d. Konten lebih kaya
e. Penggandaan murah dan mudah
f. Distribusi mudah

\subsection{Digital storytelling dan Interaktifitas}

Sejalan dengan perkembangan teknologi di bidang media dan telekomunikasi, storytelling yang sangat mengandalkan kemampuan verbal berkembang ke arah digital, yang kemudian dikenal dengan digital storytelling. Menurut Miller (2004) dalam bukunya "Digital storytelling : a creator's guide to interactive Entertainment", digital storytelling" secara dasar melibatkan beberapa komponen seperti narasi, teknologi digital, media-mikroprosesor, sinyal nirkabel, web, DVD, dan sebagainya.

Sebelum digital storytelling berkembang pesat seperti sekarang, beberapa media lama (teknologi analog) seperti seperti film, video, piringan hitam, dan kaset audio, tidak mendukung komunikasi antara penonton dan teknologi yang digunakan. Perbedaan media lama dengan media baru adalah terletak pada sisi interaktivitasnya. Digital 
storytelling menekankan terjadinya interaksi antara pengguna dengan teknologi yang digunakan. Meskipun interaktivitas menjadi pembeda antara digital storytelling dengan storytelling biasa, dalam kenyataannya, narasi yang merupakan unsur penting dalam kedua teknik bercerita tersebut tidak mengalami perubahan esensi. Namun interaktivitas memberikan efek yang mendalam pada cerita yang pada dasarnya berfungsi sebagai hiburan, pendidikan, tujuan informasi, serta komersial.

Pada dasarnya digital storytelling didorong oleh teknologi guna menemukan format baru yang lebih efisien, tepat sasaran, serta memiliki interaktivitas tinggi. Miller (2004:60) menyebutkan bahwa interaktifitas dapat dikelompokkan ke dalam 6 tipe dasar yaitu :

1. The user inputs a stimulus. Pengguna menginputkan stimulasi dan program akan menampilkan tanggapan seperti pengguna mengklik gambar kemudian terjadi sedikit urutan animasi atau terdengan suara tertentu.

2. The user can move through the program in a free manner. Pengguna dapat memilih mau pergi kemana dan apa yang akan dilakukan.

3. The user can control virtual objects. Pengguna dapat mengontrol benda-benda yang ada di aplikasi.

4. The user can communicate with other characters. Pengguna dapat berkomunikasi dengan karakter lain atau pengguna lain.

5. The user can send information. Pengguna dapat mengirim informasi. Biasanya ditemukan pada aplikasi yang terkoneksi dengan internet.

6. The user can receive or acquire things. Pengguna dapat menerim/meminta sesuatu.

Miller (2004:191) juga mengatakan bahwa dalam pembuatan aplikasi interaktif ada 10 hal yang harus diperhatikan yaitu :

1. Premise : gagasan inti aplikasi yang dibuat. Premise biasanya dapat ditulis dalam satu kalimat yang padat dan mewakili keseluruhan dari aplikasi.

2. Purpose : tujuan yang ingin dicapai dalam pembuatan apliksi, misalnya untuk hiburan, untuk menyampaikan informasi, atau untuk promosi.

3. Mode of Presentation : perangkat atau proses yang digunakan sebagai media untuk menyampaikan aplikasi agar bisa digunakan oleh pengguna.

4. Audience : targer pasar pengguna dari apliksi yang dibuat

5. Setting and Characters : latar, tempat dari cerita yang ada diapliksi serta tokohtokoh yang terlibat di dalamnya.

6. User's Role : aturan main dari apliksi. Ini menjelaskan mengenai apa yang harus dilakukan oleh pengguna dalam memainkan aplikasi

7. Goal : sesuatu hal yang bisa dicapai pengguna dalam menjalankan aplikasi

8. Opposotion and Tension : tantangan dan rintangan yang ada pada apliksi. Ini tidak mutlak harus ada dalam setiap apliksi interaktif, namun tantangan akan mempengaruhi menarik tidaknya apliksi untuk dimainkan. 
9. Reward and Consequences : hasil yang diperoleh pengguna ketika pengguna dapat melewati rintangan dan akibat yang diterima ketika pengguna tidak dapat melewati rintangan dalam aplikasi.

10. Struktur : berkaitan dengan bagaimana sebuah aplikasi ini disusun dan berjalan seperti sistem navigasi misalnya.

\subsection{Tablet Sebagai Media}

Komputer tablet adalah sebuah perangkat yang dilengkapi oleh layar lebar dengan teknologi layar sentuh (touchscreen), maksudnya adalah perangkat ini menggunakan input perintah menggunakan sentuhan pada layar perangkat. Pada awal pengembangannya di awal tahun 1980-an, komputer tablet menggunakan sistem operasi yang sama dengan komputer rumah (PC), namun pada pengembangan lebih lanjut sampai sekarang, tablet mengadaptasi sistem operasi yang sama dengan perangkat smartphone seperti iOS dari Apple atau Android yang dikeluarkan oleh Google.

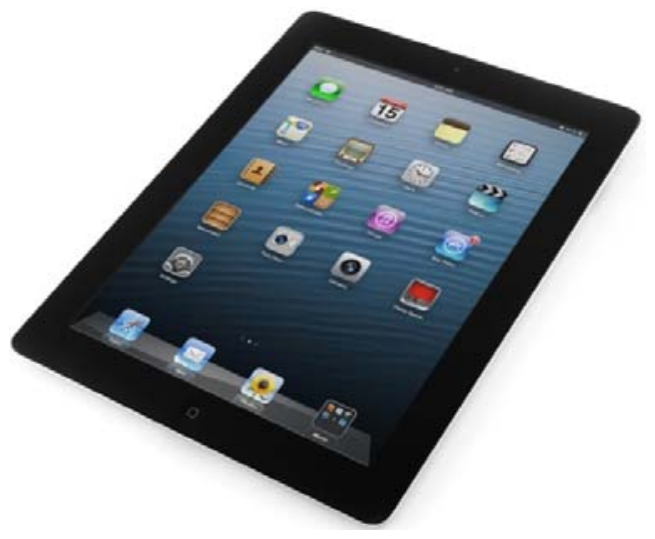

Gambar 1. Komputer Tablet

(Sumber : www.ifixit.com )

Jika dirunut perjalanan sejarahnya, perangkat komputer tablet ini dipopulerkan oleh Apple dengan mengeluarkan produk iPad generasi pertama pada tahun 2010. Kesuksesan iPad ini diawali dengan kesuksesan penjualan iPhone sebagai perangkat smartphone yang menggunakan teknologi touchscreen. Produk iPad generasi pertama ini dijual dengan tujuan perangkat konsumsi publik dengan fokus hiburan/ entertainment. Dalam statistik penjualan yang dilakukan oleh www.apple.com sebagai produsen, mereka menjelaskan bahwa produk iPad generasi pertama yang diluncurkan pada Maret 2010 terjual sebanyak 19.000 .000 unit pada tahun pertama sampai Maret 2011. Selanjutnya Apple meluncurkan produk iPad generasi 2 pada Maret 2011 dengan penjualan sebanyak 40.000 .000 unit sampai dengan September 2011. Yang paling mencengangkan adalah penjualan Apple iPad generasi 4 dan iPad Mini yang diluncurkan September 2012 yang menembus angka penjualan 3.000.000 unit hanya dalam waktu 3 hari setelah peluncuran. 
Data diatas membuktikan bahwa tingkat popularitas perangkat tablet dari Apple ini sangat tinggi di dunia. Kehadiran tablet ini mendorong produsen aplikasi dan 32 game untuk mengembangkan produk mereka. Produsen perangkat lain pun tidak mau kalah dengan mengeluarkan perangkat dengan kemampuan sejenis, seperti tablet dari Samsung dengan sistem operasi Google Android dan Kindle dari Amazon yang memfokuskan tabletnya untuk kebutuhan membaca buku digital.

\subsection{Analisis The Noah Ark sebagai Contoh Aplikasi Buku Digital}

Dengan adanya teknologi touchscreen di masyarakat, sehingga memudahkan developer untuk membuat buku digital yang interaktif dan menarik untuk dimainkan. Sebagai kompilasi buku interaktif untuk media inventarisasi cerita rakyat Demak, maka diambil sebuah aplikasi buku digital yang dijalankan pada platform android. Aplikasi interactive book yang dipilih adalah The Noah's Ark. The Noah's Ark adalah aplikasi interactive book yang dibuat oleh Tabtale developer dirilis di android market pada 5 Juli 2013.

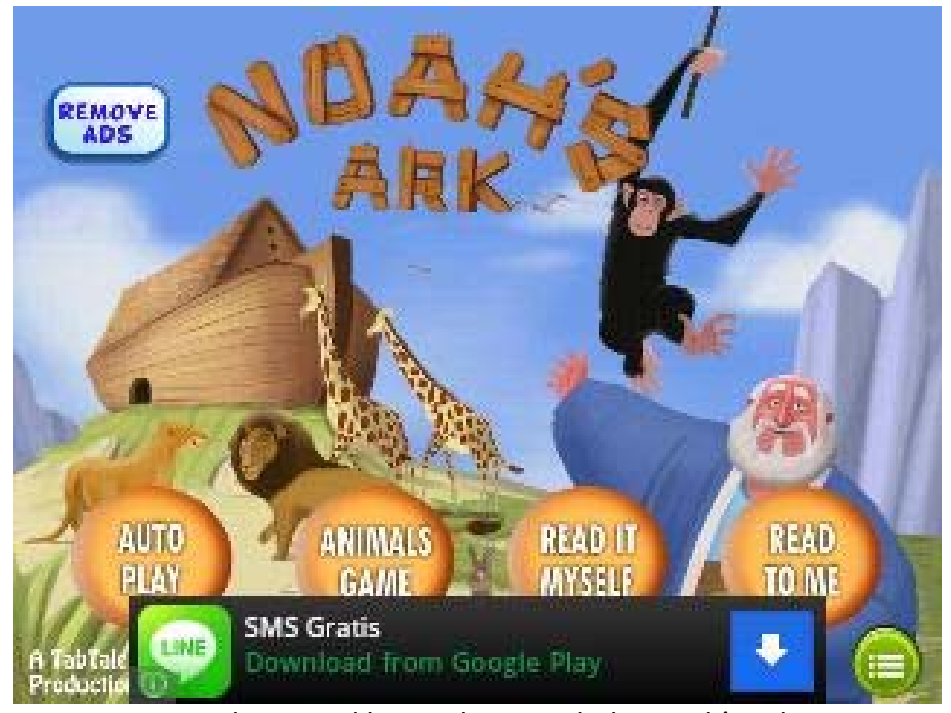

Gambar 2. Aplikasi Buku Digital The Noah's Ark

(Sumber : Google Play )

The Noahs Ark menceritakan kisah Nabi Nuh yang diambil dari cerita yang ada di Bible. Selain dirilis di Google Play aplikasi ini juga tersedia di App Store. Berikut elemenelemen dasar yang terdapat pada aplikasi The Noahs Ark : 
Tabel 1: Elemen-elemen Aplikasi The Noah's Ark

\begin{tabular}{|c|c|c|}
\hline No & Elemen & Keterangan \\
\hline 1 & Premise & Nabi Nuh dan bencana banjir bandang \\
\hline 2 & Purpose & $\begin{array}{l}\text { Untuk memvisualkan dengan lebih interaktif } \\
\text { cerita yang ada di Bible supaya pembaca lebih } \\
\text { dapat mudah memahami cerita tentang } \\
\text { penyelamatan kaum nabi nuh beserta hewan- } \\
\text { hewan dengan bahtera. }\end{array}$ \\
\hline 3 & Mode of Presentation & $\begin{array}{l}\text { Menggunakan media mobile berbasis } \\
\text { touchscreen seperti perangkat Android, Iphone } \\
\text { dan Ipad }\end{array}$ \\
\hline 4 & Audience & Anak-anak \\
\hline 5 & Setting and Character & \begin{tabular}{|l} 
Zaman nabi Nuh dengan karakternya \\
$-\quad$ Nabi Nuh \\
$-\quad$ Kaum nabi Nuh \\
$-\quad$ Hewan-hewan \\
\end{tabular} \\
\hline 6 & Use's Role & $\begin{array}{l}\text { Pengguna membaca cerita yang disajikan dengan } \\
\text { berbagai benda dan karakter virtual yang } \\
\text { interaktif yang ketika disentuh akan menyajikan } \\
\text { rangkaian animasi yang membantu memperjelas } \\
\text { isi cerita }\end{array}$ \\
\hline 7 & Goal & $\begin{array}{l}\text { Pemain memahami isi cerita dengan } \\
\text { menyenangkan }\end{array}$ \\
\hline 8 & Opposition adn tension & $\begin{array}{l}\text { Pengguna harus mengeksplor sendiri mana saja } \\
\text { item-item dan karakter-karakter yang memiliki } \\
\text { interaktifitas }\end{array}$ \\
\hline 9 & $\begin{array}{l}\text { Reward and } \\
\text { Consequenes }\end{array}$ & $\begin{array}{l}\text { Pengguna mendapatkan reaksi yang tidak } \\
\text { terduga dari interaksi item-item dan karakter } \\
\text { yang ada pada cerita }\end{array}$ \\
\hline 10 & Structure & $\begin{array}{l}\text { Aplikasi ini menggunakan struktur The String of } \\
\text { Pearls dan tidak terjadi percabangan cerita }\end{array}$ \\
\hline
\end{tabular}

Dalam aplikasi digital storytelling menggunakan media baru, konsep interaktifitas merupakan hal terpenting yang mejadikan aplikasi menarik untuk digunakan. Pada aplikasi buku digital The Noah's Ark banyak ditampilkan obyek obyek interaktif. Bendabenda dalam cerita banjir bandang yang terjadi di zaman Nuh tampil ditampilkan bergerak ketika disentuh. Burung terbang ketika disentuh, setiap binatang memasuki kapal ketika disentuh, serta benda-benda lain yang menghasilkan animasi-animasi berbeda ketika disentuh. Konsep interaktifitas pada aplikasi buku digital ini membuat penampilan buku digital yang baca lebih menarik dan terkesan lebih hidup. 


\section{KESIMPULAN}

Demak memiliki banyak cerita rakyat yang harus dilestarikan untuk mewariskan nilainilai tradisi luhur kepada generasi mendatang. Di era modern dengan pekembangan teknologi yang begitu pesat memberikan banyak pilihan menarik untuk diperhatikan dan menyisihkan cerita rakyat yang terkesan tradisional. Cerita rakyat sebagai warisan budaya luhur harus dikemas dengan cara modern supaya mendapat perhatian masyarakat di era modern ini. Aplikasi buku digital yang dibuat interaktif dengan media tablet berbasis touchscreen merupakan salah satu alternatif media untuk melestarikan dan menginventarisasi cerita rakyat dari Kabupaten Demak.

\section{DAFTAR PUSTAKA}

[1] Alaydrus, Abubakar dkk. 1994. Inventarisasi Cerita Rakyat di Kabupaten Demak. Laporan Penelitian Fakultas Sastra Universitas Diponegoro.

[2] Ardiansyah. 2012. Kajian Potensi E-Commerce Terhadap Industri Buku Digital Indonesia. Proceeding Seminar Nasional Inovasi Dan Rekayasa Teknologi (SNIRT) 2012. Program Studi Teknik Elektro UNTAG Cirebon. Hal 84 - 87.

[3] Danandjaja, J. 1997. Folklor Indonesia Ilmu gosip, dongeng, dan lain-lain. Jakarta : Pustaka Utama Grafiti.

[4] Danesi, Marcel. 2008. Dictionary of Media and Communication. New York : M.E. Sharpe, Inc.

[5] Kusmara, A. Rikrik DKK, Ed Setiawan Sabana dan Hawe Setiawan. 2005. Legenda Kertas : Menelusuri Jalan Sebuah Peradaban. Bandung : Kiblat.

[6] Miller, Carolyn Handler. 2004. Digital storytelling : A Creator's Guide to Interactive Entertainment. Burlington : Focal Press.

[7] Negroponte, Nicholas. 1998. Being Digital : Menyiasati Hidup dalam Cengkraman Sistem Komputer. Bandung. Mizan

[8] Oktalina, Lidia, Abdurahman dan Hamidi. 2013. Struktur Dan Fungsi Sosial Cerita Rakyat Si Bagejed di Jorong Sawah Mudik Nagari Batahan Kecamatan Ranah Batahan Kabupaten Pasaman Barat. Jurnal Bahasa dan Sastra Vol 1. No. 3. ejournal.unp.ac.id

[9] Prabowo, Aan dan Heriyanto. 2013. Analisis Pemanfaatan Buku Elektronik (E-book) oleh Pemustaka di Perpustakaan Sma Negeri 1 Semarang. Jurnal Ilmu Perpustakaan Vol. 2, No. 2, Tahun 2013. Hal 1 - 9. 